\title{
Education at the British Association.
}

F OLLOWING the presidential address (see NatURE, November 4), the Education Section opened its proceedings by receiving an interim report of the Committee on Training in Citizenship. The report should prove valuable to all who are interested in the welfare and future of their country. Five hundred extra copies were ordered, and are obtainable by application to the Assistant Secretary, British Association, Burlington House, W.r. It includes:-(r) A comprehensive syllabus of instruction in civics; (2) an analysis of the Scout scheme of training towards citizenship by Lt.-Gen. Sir R. Baden-Powell; (3) schemes of school management and self-government; and (4) suggestions for organising regional study, and notes of lessons in regional survey.

Bishop Welldon, who presented the report, said that training in citizenship was the chief educational interest of the day, and that he hoped a book would be issued on the lines of the syllabus with the authoritative sanction of the British Association itself.

Sir Napier Shaw, in seconding the adoption of the report, discussed the conditions that make for good citizenship, and suggested that, in the establishment of good government, only experience could guide the peoples in this matter, and that it is the business of education to enable the rising generation to profit by the experience of the past.

Mr. J. J. Clarke, of Liverpool, presented a comprehensive survey of teaching civics to adults. He defined civics as a true conception and a recognition of the incumbent duties which necessarily accompany the association of men passing beyond all question of legal contract, and forming the unseen and unforged links which bind the citizen of this vast Empire to the State. He emphasised the necessity of having teachers practically acquainted with details of their work, and inspired by high ideals and a love of the subject.

Mr. A. Patterson, of Cavendish House, contended that civics should be treated not as a special subject, not as an additional subject for the curriculum, but incidentally as part of, and as one of the chief objects in, other subjects. He urged that the teacher should be the student of civics, and hand it on transformed to the child, adapted to his range of experience and capacity. He thought that various forms of school government, and societies in which the children take an active part, are better than lessons, the children thus learning through their own experience.

The papers read before the section dealt mainly with three important aspects of educational work, viz. :--(I) The relation of schools to life; (2) methods of teaching, and the appraisement of ability in a joint meeting with the Sub-section Psychology; and (3) the place in a national system of education of universities, public schools, training colleges, and higher technical schools.

Mr. A. Linecar read a paper advocating the adoption of a general governing principle guiding all school work, such as the power of conoentration of mind. All subjects become then a means to an end, and not an end in themselves - the broader the curriculum, the broader the culture; it becomes possible then to cultivate capacity, to appreciate art, literature, beauty, Nature, and nobility without struggling to attain sectional high efficiency, to give power to be happy, and the possibility of a broad, tolerant, healthy, and full mental life.

Mr. F. M. McTavish dealt with the importance of education for the adolescent, and claimed that it was No. 2670 , KOL. IO6] through secondary education our schools are most closely related to life, for it deals with the link between childhood and manhood, and therefore on the grounds of social expediency secondary schools should be free. They only can adequately meet the need of a wellmarked stage in human growth and development, the adolescent stage. Each and all must pass through it, whether their parents live in palaces or in slums, and therefore the kind of education best suited to it ought to be available for all.

In a paper on the industrial aspects of life in its relation to schools, Mr. Bray, Assistant Controller of the Training Department in the Ministry of Labour, directed attention to the importance of awakening both employers and trade unions to their responsibilities rowards the youthful worker, claiming that up to the age of eighteen these young people should be treated as workers in course of training, and not as workers only. Statistics show that industry as a whole does not yet recognise the new status of the boy under the Education Act of I9I8; no adequate provision has been made for trade teaching, for physical welfare, or for general training. The question is a vital one: to members of trade unions it affects the well-being of their sons; to the employers the efficiency of their future workmen. The schools have a double duty: first to educate industry itself by securing a change of attitude towards the juvenile worker through industrial problems in the upper classes of secondary schools, and secondly to assist industry in the selection and training of its entrants.

An excellent paper by Miss Strudwick reviewed in a very happy form the present position of schools in their relation to life. In it she indicated some of the many causes which prevent them from being as effective as they might be, and some of the reforms which are necessary, emphasising the need for cultivating independence of judgment, an appreciation of good literature, and a profitable use of leisure. Miss Strudwick urged the value of corporate life in schools as a means of developing a sense of responsibility, unselfishness, self-discipline, and freedom of criticism. She suggested that co-education was a more natural and wholesome way of beginning life, although there were many difficulties in the way of its being adopted universally. Her plea for a fuller recognition by the nation of the importance of a teacher's work will be endorsed by all sections of the profession-" that right relation between school and life can be attained only when two conditions are fulfilled, when to those who teach their profession is a vocation and the love and confidence of their pupils a reward beyond price, and when those who do not teach are ready to accept in their midst those who do, and to make them feel that, in the best and truest sense, they belong to the world."

In the discussions that followed the Maharaj Rana of Jhalawar and Prof. Kilpatrick, of Columbia University, took part.

A joint meeting with Section $\mathrm{E}$ followed to hear a paper by Prof. J. L. Myres on "The Place of Geography in a Reformed Classical Course." Prof. Myres said that the recent decisions respecting "compulsory Greek " compelled a drastic revision of classical teaching. In place of language teaching he advocated a closer co-ordination between history, literature, and geography, and suggested that the Mediterranean region was exceptionally suited to supplement, by contrast, homeland notions of geography; the ancient narrative and description in translations of man's behaviour under these conditions, and his solutions of 
social and moral problems in ancient times compared with ours, would admirably serve as a foundation for a reformed classical education.

A joint meeting with the Sub-section Psychology was well supported. Prof. T. P. Nunn reviewed the present trend of thought respecting methods of teaching. $\mathrm{He}$ said it was generally recognised now that true learning requires the pupil to be at least an active partner in his own education, and that we have travelled far in this direction of recent years Fixed classes and fixed time-tables could not remain as they are if the individual pupil, with his distinctive powers and needs, was to be the centre of the business. Inspired by Dr. Montessori's success, courageous pioneers here and abroad are following up this revolutionary suggestion with pupils of secondary-school age.

Prof. G. H. Thompson read a paper in which he discussed the question: Do Binet-Simon tests measure general ability? He combated the conclusion based on the results obtained that the general ability evaluated by the tests was in the nature of a general common factor present in all performances.

Dr. Kimmins attracted a large audience to hear his paper on dreams of abnormal children-the deaf, blind, and crippled.

A large gathering assembled on the last morning to hear an address by the Right Hon. H. A. L. Fisher on the place of the universities in a national system of education. In Mr. Fisher's unavoidable absence the address was read by Sir Robert Blair. Mr. Fisher referred to the "general influence which universities exercise in promoting a spirit of liberal inquiry as opposed to that rigid and exclusive system of dogma which centuries ago was the product of intolerant clericalism, and is now, in modern democratic societies, preached by revolutionary or class-conscious sects." "If it be the cardinal requirement of our modern civilisation that a career should be open to talent, then it follows that universities should play a much larger part in the life of the people than historical accidents have hitherto assigned to them." He described how this enlargement was going on even before the war, and how greatly it had been increased as a result of it. In his own opinion the Government scheme of grants, whereby more than 25,000 ex. Service men are now undergoing some form of higher education in our universities and colleges, is destined to exert a permanent influence over the history of university development in these islands. In addition, our universities will be swollen by a further influx of students who otherwise before the war would have gone to Berlin or Vienna. The Education Acts of 1902 and 1918 are providing another source of recruitment through grants for secondary and continuation schools. Mr. Fisher pointed out how the work at the universities was held up for lack of funds, and hoped that private munificence will help to supplement and increase the comparatively moderate grant which the State is able to provide. A great addition to the teaching body of this country is imperatively demanded by the circumstances of the time, and he urged that the quality of the education which is to be given to the rising generations will depend upon; the extent to which the universities are enabled to leave their impress upon the teachers of our schools.

Mr. Frank Fletcher, headmaster of Charterhouse, followed with a paper on "The Public Schools in a National System of Education." Public schools at the present time could scarcely be said to form a part of a national system, but $\mathrm{Mr}$. Fletcher argued that the question of this relationship has been raised by the Teachers (Superannuation) Act of 19r8. A considerable number of public schools were unable, out of their own resources, to provide a satisfactory pension NO. 2670 , VOL. IO6] scheme; they would therefore be compelled to seek Government assistance, which would entail conditions linking them up with the national system. He claimed that no reflections of a derogatory character should apply to those who did ask for State assistance, and that those schools standing out should not be excluded from opportunities of rendering services to the State in direct connection with the national system. The form which this service might take (he said) was tentatively put forward by Mr. Fisher:-(I) That the public school should receive boys from county secondary schools the numbers of which were too small to allow of more than one type of education being given, and yet in which might be one or two boys of promise whose bent did not coincide with that of the school; (2) cooperation in the training of teachers and in the inspection of secondary schools. Mr. Fletcher urged the big public schools to accept inspection by the Board of Education rather than that of the universities, so that inspectors of the smaller secondary schools should have experience of the organisations of the larger type. Such service could be rendered without losing that individuality which was the essence of their existence. The inspectorate would then act as a clearing-house of ideas between all types of schools, and each would learn from the other and the Board from both.

Mr. J. C. Maxwell Garnett described by means of a colour diagram sixteen different types of education, showing their interrelationship, and especially the position of the higher technical schools, in what he hoped would be a national system established in the course of the next ten years.

Miss Wodehurst (Bristol University) submitted a paper on training colleges in a national system of education, and argued that there was still a need for the two-year-trained teachers as against the three- or four-year university student. She urged the desirability of keeping the entrance to the teaching profession sufficiently wide to admit those who were unable to obtain full-time courses of study, and showed that there were many sound and valuable reasons why the training colleges were better able to provide for the two-year student than the universities, especially for those who would have charge of children under twelve years of age. It is well known that capacity to profit by a training college experience extends far beyond those who can reach matriculation standard. The universities of the future could meet this need only by lowering their standards of entrance, not only for attainment, but also for ability; hence the use of the non-university college, with a staff of university-trained specialists and a governing body containing university representatives.

One afternoon was devoted to the question of the supply of teachers. An interesting discussion followed an admirable paper by Mr. Spurley Hey on the present shortage of teachers in elementary schools. The reasons for the shortage $\mathrm{Mr}$. Hey attributed to three causes:-(I) The failure of the Board of Education's policy in throwing over the pupil teachers centres and depending on the secondary school to supply recruits; (2) the failure of the Local Education Authority generally to realise the importance of taking steps to maintain an adequate supply of teachers; (3) the hostile and unsympathetic attitude of the teaching staff towards the L.E.A. in creating a supply. Mr. Hey pointed out how the Board had already taken steps to remedy this serious state of affairs by (I) its pension scheme; (2) additional grants for the payment of better salaries; (3) the establishment of the Burnham Committee; (4) providing avenues of approach to the teaching profession other than through the secondary school; (5) impressing upon the L.E.A. the need for immediate action towards 
creating an adequate supply; and he urged the Board to further action by providing more generously to. wards the preliminary education and training of teachers by exacting severe financial penalties on the defaulting L.E.A., and by amending the Teachers (Superannuation) Act so as to allow teachers to accept important educational administrative posts without loss of pensionable service. He suggested that recruits are more likely to come forward when the L.E.A. is prepared to regard existing teachers less as paid employees and more as colleagues in carrying on the educational service, and to give teachers a place in consultative and administrative work through the medilim of advisory or Whitley committees, or through mem- bership of education committees. He finally pleaded that teachers should abandon their unsympathetic attitude, and that the profession should unite in endeavours for its own expansion and improvement in the interests of education generally.

An afternoon was occupied in hearing a paper by Dr. Vincent Naser and discussing the organisation of international intellectual relations. A committee was formed to deal with the proposals brought forward. The report of the committee upon the educational value of museums was taken on the third afternoon, and the last one was spent in a very interesting and enjoyable visit to the summer school at Barry.

\section{Agriculture at the British Association.}

THE papers read at the Agricultural Section 1 covered a wide field, and included several of special horticultural interest. The section was well supported by the workers attached to the agricultural departments at Bangor and Aberystwyth, who contributed a considerable proportion of the papers. The attendance from other parts of the country was, unfortunately, rather smaller than usual.

Following the presidential address, Mr. H. V. Taylor (Ministry of Agriculture) read an important paper on "The Distribution of Wart Disease in Potatoes." This disease appears to have been recognised by Newstead so far back as 1878 , but the present serious outbreak dates from about 1898 , when specimens of infected tubers were brought to the notice of Sutton's by Kerr, of Dumfries. For a considerable number of years the areas infected by the disease were comparatively small in extent, and limited practically to Lancashire, Cheshire, Staffordshire, and the south of Scotland. Since then the disease has spread with great rapidity, and is now found in all areas north and west of a line from Newcastle to Bristol. The north-east of Scotland, however, is still quite clear. The disease is most prevalent in industrial areas, where potatoes are repeatedly grown on the same ground and where there is a less frequent change of seed. The use of infected seed is the most probable cause of the spread of the disease, and the difficulties of transport in the last two or three years have led to less frequent changes of seed and to the use of seed from infected areas. The fact that certain of the newer varieties of potatoes are very susceptible to the disease has doubtless not been without influence.

By rglo it was known that certain varieties were immune to the disease, and in I9I4 experiments were begun at Ormskirk to ascertain definitely which varieties were immune. In IgI8 the trade was invited to send in varieties to be tested, and the number under inspection greatly increased. The results of these investigations have been to show that certain varieties, such as Great Scott, King George V., Majestic, Kerr's Pink, Tinwald Perfection, Arran Comrade, Golden Wonder, Iangworth, etc., were immune to the disease. The distribution of seed from infected areas is now controlled by the Agricultural Departments of England and Scotland, and the planting in infected areas confined to immune varieties. Serious problems were involved in the administration necessary to secure adequate control. but by the energetic action of the Departments of A griculture the difficulties are being largelv overcome. The magnitude of the task involved will be realised when it is stated that some 37,500 acres of potatoes in Scotland and about 10,000 acres in England were inspected this autumn to ascertain their trueness of type. No. 2670 , voL. IO6]
Mr. F. J. Chittenden contributed a paper on "The Experimental Error in Potato Trials," describing a series of experiments which had been carried out at the Experimental Gardens of the Royal Horticultural Society at Wisley in Surrey. The paper dealt first with the various factors which influenced the yield so far as they are known at present, special attention being directed to the conditions under which the seed is grown and kept and to the treatment which it receives previous to planting. It was shown that in carefully conducted experiments when forty plants were taken the experimental error was not more than \pm 5 per cent.

Two very suggestive papers were contributed respectively by Messrs. T. Whitehead and C. L. Walton, of University College, Bangor, on "A Preliminary Report on the Parasitic Fungi of North Wales" and "The Agricultural Zoology of North Wales." Mr. Whitehead has made a survey of the chief fungoid diseases attacking the cereal and root crops of the four northern counties, while Mr. Walton has commenced an investigation into the entomological and parasitological troubles of the farmer and stockbreeder, and in particular into certain diseases affecting sheep. The work in both cases has scarcely got beyond its initial stages, but promises to yield useful results.

Capt. R. Wellington, of the Ministry of Agriculture, gave the results of "An Orchard Survey of the West of England," while Mr. R. G. Hatton described the investigations which had been carried out on fruit-tree stocks at the Experimental Station, East Malling. since I9I2. Mr. Hatton pointed out that the trade had long since discarded even the obvious dividing lines of vigour and growth characters, let alone the precise distinctions of species. The first work, therefore, was that of classification, and stocks of far greater uniformity than was available in the past are now at the disposal of future investigators.

Mr. S. P. Wiltshire described the methods of infection of apple-trees by Nectria ditissima, Tul., and the various preventive methods of treatment which had been tried.

Prof. T. Wibberley gave an account of his experiments on "Intensive Corn-Growing" in Ireland which he has been carrying on for the past ten vears. He advocated the sowing of oats very early, immediately after the ground was cleared of the first crop; at the end of September the crop was cut several times or grazed, and then manured in the spring. In this way it was claimed that heavier crons could be grown without danger of their being laid.

An important paper on "The Artificial Production of Vigorous Trees by Hybridisation" was read by Prof. A. Henry; the full paper has since been pub- 